\title{
Kunsten at organisere viden om kunsten
}

\author{
Af Anders Ørom
}

Gennem de sidste årtier har der inden for domænet kunsthistorie og kunstvidenskab været en intensiv teoretisk diskussion og fornyelse. Lyn Korenic (1997, s. 12) skelner, som det er blevet almindeligt, mellem den 'gamle', traditionelle og den 'nye', revisionistiske kunsthistorie. Som leder af et videnskabeligt 'Arts library' ${ }^{1} o g$ som forsker har Korenic både en bibliotekarisk og en videnskabelig synsvinkel på domænet. Korenics faglige udgangspunkt var en magistergrad i kunsthistorie fra 1984. Hun beskriver, hvordan domænet har ændret sig 'dramatisk' fra hun afsluttede sin uddannelse til hun godt ti år senere begyndte som ph.d.-studerende. Udviklingen fra før 1984 til 1997 kan kort skitseres således: de stilistiske, ikonografiske og kontekstuelle analysemetoder er blevet suppleret med og i nogen udstrækning erstattet af metoder fra litteraturvidenskab, filosofi, psykologi og antropologi.

Semiotik, kønsstudier, repræsentationsteorier m. . er blevet integreret i forskningen og herigennem har denne bevæget sig bort fra ,paradigms of the conti- nuity of art, fixed structures of meaning, concepts of male genius, essentialism and authority." (Korenic, 1997, s. 13). Den tværvidenskabelighed, der er knyttet til opbruddet inden for kunsthistorien, har, $\mathrm{i} g$. Korenic, ført forskere og studerende bort fra det specialiserede fagbibliotek, fordi fagbiblioteket er bygget op over det klassiske paradigme, som den 'nye' kunsthistorie har forladt. Dette er prægnant formuleret $\mathrm{i}$ artiklens titel: Inden for disciplinen, udenfor paradigmet. Det overordnede spørgsmål, som kun besvares i en skitseret, ræsonnerende form i denne artikel, er, hvorvidt vidensorganisationen på kunstmuseer, i populærvidenskab, i klassifikationssystemer, i tesauri og billedindekseringssystemer forholder sig til den teoretiske og forskningsmæssige udvikling inden for domænet.

\section{Vidensorganisation på tre 'artikulationsniveau- er'}

De tre 'artikulationsniveauer', jeg behandler i artiklen, er: 
- et første niveau, hvor genstanden for kunstvidenskaben, kunstvarkerne, organiseres i udstillinger, virtuelle museer og billedbaser. At tale om vidensorganisation på dette niveau er dels begrundet i, at kunstværkerne "rummer" udsagn og betydninger, dels i at kunstværkerne gennem udstillinger m.v. indtolkes i en sammenhæng, der er styret af viden om og synsvinkler på kunstværkerne. Dette kan også benævnes, at kunstværkerne kontekstualiseres,

- et andet niveau, hvor litteratur og andre materialer, der behandler kunstværker, organiserer deres viden i mønstre for fremstilling og forståelse, der er her tale om både (primære) forskningsdokumenter og (tertiære) formidlingsdokumenter ${ }^{2}$

- et tredje niveau, hvor klassifikationssystemer, bibliografier, tesauri og andre sekundære dokumenttyper organiserer det andet niveaus litteratur og materialer (og i nogle tilfælde også kunstværkerne).

Denne afgrænsning gør, at vidensorganisation inden for domænet kunsthistorie og kunstvidenskab ikke behandles konkret og analytisk på et videnskabssociologisk niveau. ${ }^{3}$

Artiklen fokuserer på de diskurser om kunsten, der kommer til udtryk på de tre 'artikulationsniveauer'. Brugen af begrebet 'artikulationsniveauer' implicerer en antagelse af, at historisk bestemte diskurser om kunsten 'gennemsyrer' alle tre niveauer. Det kan også formuleres på den måde, at den sociale og institutionelle praksis for udstilling af kunstværker (niveau 1) indskriver sig i og virker tilbage på måden kunsten anskues og behandles på i litteratur og andre materialer (niveau 2); endvidere er de sekundære dokumenttyper (niveau 3) i stor udstrækning præget af begrebsbrug og synsvinkler fra primærlitteraturen. (Ud over denne prægning er der også tale om prægning af organisationsprincipper fra biblioteks-, dokumentations- og informationsvidenskaben i form af 'matricer' som hierarkiske klassifikationssystemer og tesauri).

Begrebet diskurs anvendes med udgangspunkt i
Schaanning (1997). Schaannings bog bygger på værker af Michel Foucault og George Latour og fokuserer på den videnskabelige viden som viden skabt gennem den videnskabelige virksomheds praksisser, en diskurs kan kort bestemmes som et 'sæt af udsagn', der stammer fra samme tilblivelsessystem, dvs. samme disciplin, eksempelvis kunsthistorie og kunstvidenskab. Diskursen er indvævet i ting og samfundsforhold. Med (en drejning af) Latours diskursbegreb kan dette eksemplificeres således inden for kunstinstitutionen: Den kunstvidenskabelige diskurs er 'indvævet' i kunstmuseerne og 'viser sig' $i$ indretningen og måden at præsentere kunstværkerne på, i udstillingspraksissen. Museernes praksis og den kunstvidenskabelige forskning og formidling hænger sammen med penge, politik, prioriteringer, ideologi og følelser, og gennem disse er diskursen 'indvævet' i samfundsforhold. Begrebsproduktionen inden for den kunstvidenskabelige diskurs baserer sig, ligesom inden for andre videnskabelige diskurser, på forskellige vidensdiscipliner (her brugt $\mathrm{i}$ vid betydning spændende fra økonomi til idéhistorie og fra psykologi til farvekemi). Sagt på en anden måde indskriver den kunstvidenskabelige diskurs sig i et kompleks af diskurser.

\section{Kunstværkernes organisering}

I studieordningen for kunsthistorie ved Københavns Universitet bestemmes stofområdet således:

„Studier i kunsthistorie omfatter kunsten (primært billedkunst og arkitektur) og dens historie i alle dens aspekter og til alle tider. Grundlaget for studiet af kunstens historie er kunstværkerne."

To aspekter er her centrale: dels det at kunstværkerne bestemmes som fagets genstand - i sidste instans -, dels det, at denne genstand studeres under en historisk synsvinkel. Dette forekommer umiddelbart indlysende, da det netop drejer sig om kunsthistorie. Uden at formuleringen sidst i citatet kan tages til indtægt for en traditionelt, essentialistisk kunstopfattelse, kan denne formulering bruges til at skitsere den traditionelle opfattelse, der selvstændigg $\varnothing \mathrm{r}$ 
kunstværket og opfatter det som bærer af bestemte betydningsfulde former, harmoniske kompositioner, et særligt betydningspotentiale eller lignende, der kan betragtes som essentielt.

Ser man på den tilsvarende formulerings for studiet ved Aarhus Universitet, får man en anden implicit definition af, hvad kunsthistorien omfatter og har som genstand:

„Kunsthistorie beskæftiger sig med synets kultur. Centrale spørgsmål er her, hvad æstetik er, og hvad det gør kunst til kunst? Således søger vi at indkredse kunstinstitutionen som sådan og retter opmærksomheden på ere forskellige problemstillinger som for eksempel forholdet mellem værk og kunstbegreb, værk og beskuer samt kunst og offentlighed. Ellers ligger hovedvægten på den europæiske udvikling inden for kunsten med særligt fokus på middelalder, renæssance, barok og modernitetens opståen og udvikling frem til i dag. Det kunsthistoriske område omfatter udover de klassiske værktyper (maleri, skulptur og arkitektur) også fænomener som video, installationer og design (inklusiv mode). ${ }^{65}$

Genstandsområdet bestemmes som 'synets kultur', knyttet til kunstinstitutionen. Endvidere er et bredere værkbegreb understreget. Med denne bestemmelse får opfattelsen af kunsthistorien en kulturvidenskabelig og sociologisk drejning. Første halvdel af citatet er udtryk for en teoretisk og analytisk beskæftigelse med kunsten og kunstinstitutionen, herigennem lægges vægten på det kunstvidenskabelige. Formuleringen er udtryk for den 'nye' kunsthistorie. Anden halvdel af citatet beskriver de perioder og det geografisk-kulturelle rum, der er genstand for den kunsthistoriske behandling. Med brugen af begreber som 'installationer' og 'kunstinstitutionen' markeres en nærmere tilknytning til den samtidige kunst og til institutionsteorien, der er udtryk for det aktuelt herskende kunstsyn. Udgangspunktet for institutionsteorien er det netværk af relationer, kunst indgår i. Kunstværket er et delaspekt af kunstinstitutionen og bestemmes i relation til ophav, andre kunstværker, kunstkritik, museer osv. Hvad der er kunst, afgøres af - eller i - kunstinstitutionen.

Ligesom det for den traditionelle kunsthistorie gælder, at kunstværket sættes i fokus, således gælder dette også for kunstmuseernes almindelige udstillingspraksis. Beskrivelser og vurderinger af kunst har deres udgangspunkt i kunstværket. Det at skrive om kunst er historisk udsprunget af mødet med kunstværker på udstillinger og kunstmuseer. Kunstværkerne, der skrives om, var og er generelt organiseret i offentligt tilgængelige rum: byrummet, udstillingssteder og museer. På udstillingssteder og museer er kunstværkerne organiseret i en „ophængningsorden“, der kan være styret af æstetiske kriterier, kunstarter, genrer, motiver, historiske forl $\varnothing \mathrm{b}$ eller andet. Det at skrive om kunst, og dermed det gennem skrivningen at organisere viden om kunst, hænger i høj grad sammen med en udstillingspraksis. Forstået på denne måde ligger der allerede i udstillingspraksissen et syn på kunst, der er betinget af og virker tilbage på måden at skrive på. En ophængning på et kunstmuseum er således en form for vidensorganisation samtidig med at det er en organisation af genstandene, kunstværkerne, i bestemte rum. Organisationen af kunstværkerne i rummet udtrykker en opfattelse af deres karakter og indbyrdes forhold. Den klassiske udvikling af et kunstmuseums faste samling er opbygget kronologisk og kategoriseret ud fra kunsthistoriske perioder, stilretninger og -ismer, nationer eller geografisk kulturelt afgrænsede områder, som det også ses i nyophængningen på Statens museum for Kunst. Denne vidensorganisation er på det nærmeste indbygget i museernes historisk udviklede samfundsmæssige funktion:

"Traditionelt fungerer kunstmuseerne som de steder, hvor samfundet indsamler, registrerer, udforsker og formidler de kunstværker, der af historien er anerkendt som en del af kulturarven. Det er ifølge museumsloven museernes opgave netop gennem disse funktioner at sikre Danmarks kulturarv og belyse kultur- og kunsthistorien. Det historiske perspektiv er således en integreret del af museernes væsen, og den traditionelle opgave 
med at opsamle og belyse kaldes under ét den museale." (Bunkenborg, C \& Lommer, K1995, s. 17-18)

Noget tilsvarende gælder også for organisationen af repræsentationer af genstandene via reproduktioner i museumskataloger, indekser og virtuelle museer, hvor forståelsen af 'udstillingsordenen' funderes i verbale beskrivelser af kunstværkerne. Anderledes formuleret indgår museumsudstillingen i en diskurs om kunsten. I grove træk kan kunstmuseernes udstillinger af værker fra de faste samlinger siges at være organiseret i en kronologisk orden, hvor de enkelte kunstværker repræsenterer perioder, stilarter og -ismer. Gennem danske kunstmuseers udstillinger vises dele af den nationale og vestlige kunstneriske kulturarv. Ud over at kunstværkerne vises, indskrives de en bestemt forståelse, som kan karakteriseres ud fra kunsthistorieskrivningen.

\section{Vidensorganisation i kunsthistoriske fremstil- linger}

I en artikel med titlen Historiske konstruktioner analyserer Hans Dam Christensen blandt andet vidensorganisationen i Janson'ernes: Verdenskunstens historie, der er et hoved- og standardværk inden for domænet kunst- og arkitekturhistorie. Dam Christensen skriver:

„Gennem sin udbredelse er Janson'ernes bog med til at præge faget kunsthistorie og opfattelsen af kunsthistorie i det hele taget." (Dam Christensen, 1999, s. 88).

Ud over at Janson'ernes bog er med til at præge opfattelse af kunsthistorie i det hele taget i den kulturelle offentlighed, kan det også hævdes, at dens opfattelse svarer til opfattelsen bag kunstmuseernes traditionelle udstillingspraksis. Et af de centrale problemer er, at et standardoversigtsværk som Janson'ernes tilhører et paradigme, der i stor udstrækning er upåvirket af nyere teoretiske positioner inden for kunsthistorien. Ifølge Dam Christensen indebærer dette paradigme, eller den historiske kon- struktion, som det kaldes, forestillingen om national kunst (og national identitet) og forestillingen om, at den europæiske kunst har en særstatus. Denne særstatus kan bl.a. a æses af den måde ikke-europæisk kunst behandles på, nemlig som indledende stadier eller senere bidrag til den europæiske kunst. Når den ikke-europæiske kunst har fuldført sin mission, nemlig at skabe forudsætninger for forståelse af den europæiske kunst, glider den ud af fremstillingens perspektiv.

For den traditionelle kunsthistorie gælder det, stadig ifølge Dam Kristensen, at kunstværket sættes i betydningens centrum. De kunsthistoriske oversigtsværker fremstiller og organiserer dermed kunstens historie baseret på en sekvens af kanoniserede værker, knyttet til de kunstnere, der er deres ophav. Dam Christensen (1999, s. 90) formulerer det således: „,...) skabelonen for kunstens historie tilbyder en perlerceke af kunstvarker og kunstnere som afscet for sin fortcelling." Den overordnede ramme er altså en kronologisk ordnet stilhistorie, og inden for denne ramme organiseres de kanoniserede værker og kunstnere, ofte med en personhistorisk optik på beskrivelsesniveauet under stilhistorien. Den stil- og personhistoriske optik løber sammen i værkcentreringen. Det samme karakteriserer den traditionelle udstillingsform på kunstmuseer.

Det overordnede princip for vidensorganisationen er kronologisk, stilhistorisk. Bag dette princip ligger forestillinger om nationalitet og udvikling. Forestillingen om nationalitet kan idéhistorisk føres tilbage til tiden omkring Den franske Revolution. Nationalitetsforestillingen og det ældste lag af udviklingstænkning er begge præget af Herders tænkning. Det senere lag i udviklingstænkningen er præget af Darwins evolutionsopfattelse.

Nationalitetstanken var en overordnet forestilling i den danske kunstdiskurs fra slutningen af 1700-tallet til omkring 1880. I Mellemkrigstiden kom den igen markant ind i kunsthistorien. Denne historiske begrebsprægning overlever fortsat i dansk kunsthi- 
storieskrivning (Dansk kunsthistorie og Ny dansk kunsthistorie $)^{6}$.

Kunsthistorikeren Erik Mortensen (1990, bind 1, s. 19-20) skriver kort om de politiske begivenheder i Danmark i slutningen og føjer til:

\begin{abstract}
„Billedkunsten påvirkedes umiddelbart af begivenhederne. Men der skulle gå en længere årrække, inden de fulde konsekvenser blev trukket. Den danske kunst blev dansk i tre faser: 1 . den danske kunst bliver en kunst skabt af danske kunstnere; 2. den bliver dansk i kraft af danske motiver og emner; 3. den bliver dansk som følge af sit særlige udtryk, sin stil. Ingen af delene havde den været i perioden fra renæssancen til sidste halvdel af 1700-tallet.“
\end{abstract}

Hvad det andet punkt angår er det historie, sagn, myter og natur, der kommer til at udgøre den nationale emnekreds. Den nationale kunsthistoriekonstruktion fremtræder i de to nævnte, nyere fremstillinger af dansk kunst historie som naturlig, trods det, at det er specifikt historisk udviklet forestilling. $\mathrm{Ud}$ fra Latours opfattelse af videnskaben kan der kastes et sidelys over denne naturalisering af forestillinger. Latour (Schaanning, Espen, 1997, kapitel 8) beskæftiger sig med naturvidenskaben og skriver, at bedrive videnskabelig er at transformere spekulationer og usikre påstande til noget, der fremtræder som fakta og utematiserede antagelser. På domæneniveau kan dette overføres til kunsthistorien med en ændring af termerne. Også her gælder det, at bestemte forestillinger starter som udkast og ender som utematiserede antagelser, eller med Dam Christensens begreb: historiske konstruktioner.

Når vi bevæger os fra kunsthistorie på nationalt niveau til kunsthistorie på europæisk niveau er forestillingen ligeledes præget af Herder (Schaanning, Espen, 1997, s. 19). Fra ham kommer idéen om, at den europæiske kultur ,er folkeslagenes værk, men i et successivt forl $\varnothing b$." Et folk udvikler sig og udvikler kulturen til en guldalder, derefter forfalder kulturen, men det, kulturen er resulteret i, overtages af andre folkeslag. Denne forestilling - eller konstruktion - kan fortsat hævdes at være styrende for vidensorganisation inden for kunstfeltet. À propos termen felt kan det indskydes, at Herder så en sammenhæng $i$ en kultur, der omfattede en række delaspekter, ordnet i begrebsfølgen: nation - folk - natur - historie - sprog - digtning - kunst. (Schaanning, Espen, 1997, s. 19).

Med brug af nogle begreber, der er formuleret af Foucault (Schaanning, Espen, 1997, s. 8-10 og 1518) kan kunstens historie betragtes under samme synsvinkel som videnskabernes historie. Sammenvævningen af kunst og kunsthistorie betragtes som en diskursiv formation. I sin kritik af traditionel videnskabshistorie skelner Foucault mellem to typer: internalistisk og eksternalistisk. I den førstnævnte forklares videnskabens udvikling ud fra videnskabsinterne forhold; i den anden ud fra videnskabseksterne faktorer. Det, der karakteriserer den internalistiske forståelse er præsentisme: videnskaben forklares ud fra dens aktuelle situation. De træk i udviklingen, der peger frem mod den aktuelle situation, bliver styrende for - og afgrænser indholdet $\mathrm{i}$ - den historiske fremstilling. Når Dam Christensen skriver, at det lineære forl $\varnothing \mathrm{b}$ tenderer til at gøre stilens historie til det teleologiske mål, er det en anden måde at formulere præsentismen på. De historiske kunstværker, vi ser på kunstmuseerne er, ligesom det kunsthistoriske oversigtsværk, organiseret 'teleologisk', de udstillede og behandlede værker, er kanoniske, de viser hvordan kunsten har udviklet sig, set ud fra en præsentisk synsvinkel.

Foucaults kritik af de to traditionelle typer videnskabshistorie går på, at videnskabens og andre diskursive formationers ,,inderside“ og ,yderside“ ikke kan adskilles; magt og viden betinger hinanden, de videnskabelige discipliner er samfundsmæssige praksisudøvelser. I stedet for disse opfattelser sætter Foucault systemkontrastering og genealogisering. Forståelsen, der ligger bag denne systemkontrastering, er, at vor tids vidensdiscipliner er fundamentalt forskellige fra tidligere. Ved at fokusere på forskellene kommer overgangene og de diskontinuerlige 
systembrud frem i forståelsens lys. Genealogiseringen genfinder gamle diskurser og praksisser som elementer i den nye diskursive formation. Denne relationelle opfattelse af kunsthistorien, som jeg satte i forbindelse med citatet fra studieordningen for kunsthistorie på Aarhus Universitet, kan ses i dette perspektiv. Når et kunstværk fra det 18. århundrede sættes ind en samtidig betydningskontekst, kan forskellene mellem den samtidige og den nutidige 'praksisudøvelse' inden for feltet kunst komme til udtryk.

At synsvinklen i traditionel kunsthistorie er æstetisk er et markant udtryk for den internalistiske forståelse. Kunsten udvikler sig af sig selv og i sig selv, upåvirket af magten og den samfundsmæssige praksis, som kunsten udspringer af, upåvirket af institutionshistorie og dermed af ændringer i institutionernes praksisser og forståelse af, hvad kunst er.

\section{Vidensorganisation i Janson'ernes Verdenskun- stens historie}

Flere af de traek, der karakteriserer den traditionelle kunsthistorie, findes i Janson'ernes Verdenskunstens historie. I dette oversigtsværk er fortællingen konstrueret ud fra Vesten/Europa. Indholdsfortegnelserne i den danske oversættelses tre bind viser principperne for vidensorganisation. I bind 1 startes der omkring 15.000 år fvt. med det forhistoriske menneskes kunst. Dvs. den historiske fremstilling går tilbage til den ældre stenalders hulekunst. Inden der gås videre med den ægyptiske kunst, er der et afsnit om primitiv kunst. Fra Ægypten følges kronologien videre gennem de følgende betydende oldtidskulturer: den sumeriske, den assyriske og den persiske. Herefter bevæger fremstillingen sig ind i Europa med den ægæiske kunst og i forlængele heraf den græske kunst, der primært kategoriseres i stilarter og perioder. Efter græsk kunst følger etruskisk, romersk, tidlig kristen og byzantinsk. I bind 2 behandles kunststen i middelalderen og renæssancen samt manierisme og barok. I behandlingen af middelalderen startes der udenfor Europa med islamisk kunst.
Den del af indholdsfortegnelsen, der dækker romansk kunst, kan illustrere nogle centrale vidensorganisationsprincipper:

\begin{tabular}{|c|}
\hline Romansk kunst \\
Arkitektur \\
Sydvestfrankrig \\
Bourgogne og Vestfrankrig \\
Normandiet og England \\
Lombardiet \\
Tyskland \\
Toscana \\
Skulptur \\
Malerkunst \\
$\ldots$. \\
Nicholas af Verdun \\
Gotisk kunst
\end{tabular}

På „1. ordens“ niveau er kategoriseringskriteriet stilarter/perioder, på „2. ordens“ niveau er det kunstarterne arkitektur, skulptur og malerkunst, på ,3. ordens niveau“ er der anvendt geografisk-kulturelle områder. Endvidere er der brugt et kunstnernavn som kriterium. I fremstillingen af kunsthistorien fra gotikken og frem bliver kunstnernavne brugt i stigende omfang, og stiltermerne samt opdelingen på kunstarter bliver mere differentieret. Et eksempel på dette er værkets organisering af fremstillingen af gotisk malerkunst:

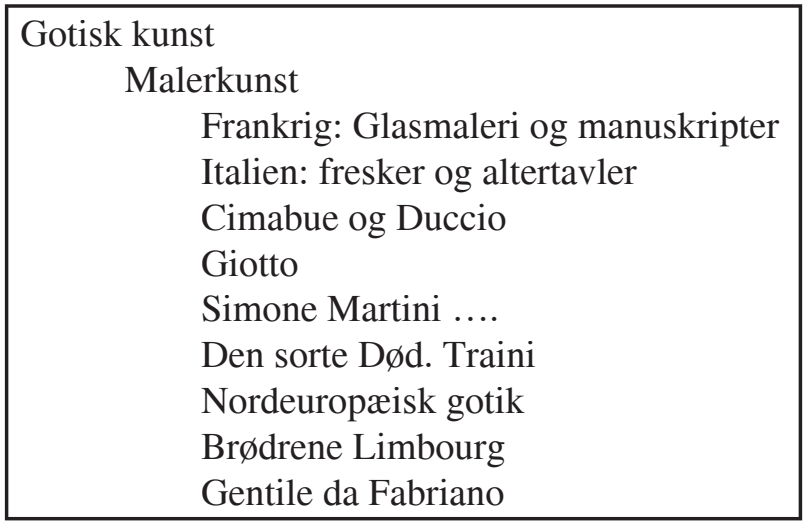

Organiseringen af stoffet om renæssancen følger 
de samme principper, der lægges dog mere vægt på enkeltkunstnere (koblet sammen med hvor de virkede), dertil kommer enkelte kunstværker (Det sixtinske Kapel, Medici-kapellet, il Gesù kirken). Men det sidstnævnte gælder kun for afsnittet om renæssancen, der generelt har en privilligeret stilling i den klassiske kunsthistorie. Kategoriseringen af stoffet, der behandler barok, nyklassicisme, romantik, realisme, impressionisme og postimpressionisme - alle på „1. ordens“ niveau - koncentrerer sig om Rom, Flandern, Holland, Spanien, Frankrig, England samt Amerika, der kommer ind i billedet med nyklassicisme og romantik. - Landene eller de geografisk-kulturelle områder befinder sig i denne fase af kunsthistorien på ,2. ordens" eller ,3. ordens“" niveau. Landene forbindes kategoriseringsmæssigt med centrale kunstnere, ,perlerækken“. Det kan illustreres med malerkunsten inden for nyklassicisme og romantik:

\begin{tabular}{|l|}
\hline Nyklassicisme og romantik \\
Arkitektur \\
$\ldots$. \\
Malerkunst \\
Amerika: West og Copley \\
England: Stubbs og Füssli, Blake og \\
Cozens \\
Tyskland: Friedrich \\
Frankrig: Greuze \\
$\ldots .$. \\
Skulptur \\
$\ldots .$. \\
\hline
\end{tabular}

I bind 3 udvides det geografisk kulturelle perspektiv, idet Mexico inddrages og idet der er et efterskrift om mødet mellem $\varnothing$ st og vest. Som det kan ses er perspektivet på vidensorganisationen i Janson Verdenskunstens historie i første instans eurocentrisk og „maskulint“, i anden instans kommer Nordamerika (primært USA, sekundært Mexico og præ-columbiansk Amerika) ind i perspektivet. Den ,gamle“ verdens kunst frem til den ægæiske ses som forløber den europæiske kunst.

En af Dam Christensens centrale pointer er, at den 'nye' kunsthistorie, forskningen udenfor det para- digme, som Janson'erne repræsenterer, ikke slår igennem i de populariserede dokumenttyper, der henvender sig til den kulturelle offentlighed. I de kunsthistoriske oversigtsværker og i den mest udbredte dokumenttype, populærvidenskabelige kunstnermonografier, overlever den traditionelle kunsthistories forståelsesformer og vidensorganisationsprincipper. ${ }^{7}$

Universelle vestlige klassifikationssystemers organisation af litteratur om kunsten

Dam Christensen henviser til en bog $^{8}$, hvor Library of Congress Classification kritiseres for - på linie med fremstillinger som Janson'ernes - at være en del af kunsthistoriefagets ,,skjulte magtudøvelse og værdihierarkisering“. (Dam Christensen, 1999, s. 98).

Library of Congress Classification System, LCCS (SuperLCCS, 1998) har de visuelle kunstarter under $\mathrm{N}$; kategoriseringen er således:

N. Visuelle kunstarter

NA: Arkitektur

NB: Skulptur

NC: Tegning, design, illustrationskunst

ND: Maleri

NE: Trykmedier

NK: Dekorativ kunst. Anvendt kunst, dekoration og ornament

NX: Kunstarterne generelt

Til forskel fra Verdenskunstens historie, er det overordnede vidensorganisationsprincip ikke historisk, men systematisk opdelt på kunstarter. Maleri er inddelt således: 
Maleri

Generelt (Samlede værker, encyklopædier, catalogues raissonnés $\mathrm{m}$. dokumenttyper) Historie

Studium og undervisning

Generelle værker

Specielle motiver

Menneskelegemet

Portrætter

Landskabsmaleri

Marinemaleri

Dyr, Fugle

Stilleben

Blomster. Frugt

Andre motiver

Teknikker og materialer

Akvarelmaleri

Murmaleri

Illumination af manuskripter og bøger

Under historie er organisationsprincipperne en kombination af dokumenttyper, perioder og stilarter. Nedenfor skitseres organiseringen af perioder og stilarter:

\begin{tabular}{|c|}
\hline Historie \\
Oldtiden \\
Ægyptisk \\
Klassisk \\
Græsk \\
Oldtidens Italien \\
Romersk \\
Etruskisk \\
\\
Middelalderligt og moderne maleri \\
Middelalderligt \\
Karolingisk \\
Byzantinsk \\
Romansk \\
Gotisk \\
Islamisk maleri
\end{tabular}

Herefter er organisationsprincippet århundreder for det moderne maleri, dvs. fra renæssancen og frem. En central og omfattende sekvens under historie er ordnet efter lande, og inden for landene er kunstnerne ordnet alfabetisk efter navne.

Dewey Decimal Classification (Dewey, M, 1990) opdeler ligesom LCCS efter kunstarter (der i Dewey som i DK 5 også omfatter musik og ,recreational \& performing arts“").

Gruppe 750: Maleri og malerier er organiseret væsensforskelligt fra LCCS:

751: Teknikker, udstyr, former

752: Farve

753: Symbolik, allegori, mytologi, legende

754: Genremaleri

755: Religion og religiøs symbolik

756:

757: Menneskelegemet og dets dele

758: Andre motiver

759: Behandlinger af historie, områder og personer

Som det ses, er der primært organiseret ud fra et symbolik- og motivniveau, eller anderledes formuleret ud fra et ikonografisk niveau.

De historiske undergrupper (under 759) er håndfast kronologisk afgrænsede:

759.01: Folk uden skiftsprog og de tidligste tider til 499

759.02: $500-1399$

759.03: $1400-1599$

759.04: $1600-1799$

759.05: $1800-1899$

759.06: 1900-1999

759.07: 2000-2099

Bag den første undergruppe kan der anes en traditionel evolutionstænkning: skriftløse kulturer placeres uanset deres historiske tidsrum sammen med den tidligste historie. Det overordnede periodiseringsprincip er 'mekanisk' og re ekterer kun indirekte og i begrænset omfang specifikke træk ved kunstens udvikling. Det indirekte ligger i, nogle kronologiske 
afgrænsninger falder sammen med periodiseringer, der anvendes i kunsthistorien (oldtid, middelalder, og omtrentligt renæssance).

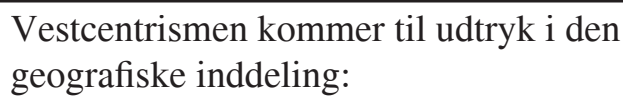

759.1: Nordamerika

759.2: De britiske Øer

759.3-8: Andre europæiske lande

759.9: Andre geografiske områder

Der er nogle forskelle mellem de her behandlede vidensorganisationsstrukturer, og der er fællestræk. Nogle af forskellene er betinget af dokumenttypen. Det kunsthistoriske oversigtsværk behandler direkte kunstens historie. Klassifikationssystemerne kategoriserer de kunsthistoriske dokumenter ud fra en systematisk tilgang og med dokumenttypologi som facet. Ud over at den overordnede systematik er baseret på kunstarter, der afgrænses forskelligt i de to klassifikationssystemer, trækkes motivkategorier og dermed det ikonografiske niveau frem som distinktionskriterium. Dette kan sikkert ses som et udtryk for, at klassifikationssystemerne er blevet prægede af den humanistisk-åndshistoriske retning inden for kunsthistorien, der fokuserer på symbolet i kunsten, på indhold og ikonografi.

Blandt fællestrækkene er det lineære, kronologiske forløb (på forskellige „ordeners“ niveau), vestcentreringen, og den deri indbyggede forestilling om Europa og Nordamerika som kulminationen på kulturhistorien. Endvidere afspejler Janson'ernes værk og de to klassifikationssystemer den internalistiske tilgang til kunsthistorien samt præsentismen.

Med klassifikationssystemerne befinder vi os, ligesom med oversigtsværker som Janson'ernes, på det Dam Christensen (1999, s. 99) kalder ,den disciplinære underbevidstheds niveau“, et niveau:

„hvor vi producerer betydning uden at tænke over hvorfor og hvordan. Denne ubevidste handlen, systemernes eller strukturernes tilsyneladen- de indlysende eller ,naturaliserede“ inddelinger, er med til at bevare bestemte værdihierarkiseringer eller vidensregimer, der altid tager udgangspunkt i særlige sociokulturelle faktorer og således privilegerer disse på bekostning af andre fortællinger.“

Disse „,naturaliserede“ vestlige vidensregimer kan sættes i relief gennem en sammenligning med et sovjetisk klassifikationssystem.

Det sovjetiske bibliografisk-bibliotekariske klassifikationssystems organisation af kunsten

I det sovjetiske klassifikationssystem, $B B K$, er kunst og kunstvidenskab placeret i gruppe SC (Bibliothekarisch-bibliographische Klassifikation,1968, bind 21, s. 389-390), hvilket viser, at kunsten er et fænomen i den kulturelle overbygning. Hovedstrukturen er, i modsætning til den filosofisk-idealistisk baserede overordnede kategorisering i de to nordamerikanske systemer, således:

Marxisme/ leninisme

Naturvidenskaber

Samfundsvidenskaber

Kultur. Videnskab. Folkeopdragelse/

folkeoplysning (Volksbildung)

Filologiske videnskaber. Skønlitteratur

Kunst. Kunstvidenskab

Religion. Ateisme

Filosofiske videnskaber. Psykologi

Litteratur med universelt indhold

I hovedgruppen kunst og kunstvidenskab indgår bl.a. - ud over arkitektur, skulptur, maleri og grafik -kunstnerisk fotografi, musik, dans, teater og filmkunst, samt nogle kunstformer og -fænomener, som ikke findes inden for LCCS og Dewey, nemlig kunstneriske radio- og fjernsynsudsendelser samt massearrangementer og folkefester. 
Gruppe SC 10 visuel kunst (bildende Kunst) er i (udvalgte) hovedtræk organiseret som angivet nedenfor:

Marxismens/leninismens klassikere om visuel kunst

Kunstvidenskabens metodologi

Partiskhed i kunstvidenskaben

Kritik af ikke-marxistiske teorier

Kunstvidenskabens og kunstkritikkens historie

Almen kunstvidenskab

Kunstvidenskaben i Sovjetunionen

Frem til den store socialistiske Oktoberrevolution

Sovjetisk kunstvidenskab og kunstkritik

Organisation af det videnskabelige arbejde på den visuelle kunsts område

Organisation af det videnskabelige arbejde i Sovjetunionen

Kunstnerisk uddannelse

Kunstnerisk uddannelse i Sovjetunionen

Kunstnerisk udd. indtil den store socialistiske Oktoberrevolution

Bibliografi, opslagsværker

En række andre dokumenttyper

Teori om den visuelle kunst

Bevaring af kunstværker. Kunstmuseer og kunstsamlinger

Den visuelle kunsts almene historie

Visuel kunst i ursamfundet

Visuel kunst i oldtiden

Visuel kunst i det antikke Grækenland

…

Visuel kunst i det 5. - 18. århundrede

Ungrenæssance

Højrenæssance

Visuel kunst i det 19. århundrede

Visuel kunst i det 20. århundrede (fra 1917)

Visuel kunst i Sovjetunionen

Visuel kunst i udlandet

Europas visuelle kunst

Asiens visuelle kunst

Afrikas visuelle kunst

Amerikas visuelle kunst

Australiens og Oceaniens visuelle kunst 
BBK er indskrevet i Sovjetmarxismens videnskabsideologiske diskurs og har dermed et perspektiv på den visuelle kunst som adskiller sig markant fra perspektivet i LCCS og Dewey systemerne. Perspektivet på den visuelle kunst er i BBK overordnet marxistisk, hvilket dels kommer til udtryk ved, at marxistisk teori og kunstvidenskab sættes som norm, dels ved at der er lagt stor vægt på videnskabshistoriske, videnskabssociologiske og institutionelle sammenhænge. Dette kan ses i forhold til de to nordamerikanske systemer, hvor det videnskabshistoriske ikke træder frem, og hvor det videnskabssociologiske aspekt er fraværende, der mangler altså det aspekt, der drejer sig om forskningens organisation. Det sociologisk-institutionelle aspekt, kunstinstitutionen som ramme for kunstfrembringelse, -formidling og konsumtion, er i de nordamerikanske systemer stærkt nedtonede. LCCS har gruppen studium og undervisning. Generaliseret kan det siges, at LCCS og Dewey tager udgangspunkt i kunsten som et autonomt fænomen.

Et fællestræk ved de tre systemer er, at inddelingen på ,1. ordens" niveau er baseret på kunstarterne, selvom disse afgrænses og uddifferentieres på forskellig måde. I LCCS er hovedgruppen afgrænses til visuel kunst, i Dewey og BBK indeholder hovedgruppen også eksempelvis musik og film.

Et andet fællestræk er, at de tre systemer har kronologisk ordnede undergrupper for kunstens historie. LCCS kombinerer historiske perioder, kunsthistoriske perioder og kunstretninger i sin periodiseringsorden. Det samme gælder BBK, der for den nyere tids vedkommende bruger Oktoberrevolutionen som et centralt periodiseringskriterium. Dewey bygger sin grundstruktur på en kronologisk orden (et eller ere århundreder) der ikke baserer sig (eksplicit) på historiske eller kunsthistoriske periodiseringsprincipper.

LCCS og Dewey har, som nævnt, en vestcentreret struktur i lighed med Janson'ernes Verdenskunstens historie. I BBK er der også en form for Sovjetcentrisme, men den adskiller sig i sin karakter fra de nordamerikanske eksempler på vidensorganisation. Hvor hele optikken på kunstens historie i de nordamerikanske systemer fokuserer på udviklingen af europæisk og nordamerikansk kunst og denne udviklings forløbere (i Nærorienten og Ægypten), har det sovjetiske system ikke det samme snævre præsentisk bestemte geografiske fokus. Der er en differentieret udfoldelse af begrebsstrukturen, der dækker kunsten i Sovjetrepublikkerne; men på den anden side er den visuelle kunst i udlandet også udfoldet og ikke underlagt en teleologi af den type, der styrer organisationen af den vestlige kunst i de nordamerikanske systemer.

Vidensorganisation i en tesaurus, $i$ et billedklassifikationssystem og i et virtuelt museum: Art \& Architecture Thesaurus, Iconclass og Det virtuelle Kunstmuseum

I Bouchon (1997) behandles Jules Maciets encyklopædiske billedsamling i Bibliothèque des Arts décoratifs i Paris. Denne samling, der blev oprettet i det 19. århundrede er overordnet inddelt i 62 alfabetisk ordnede klasser. Det interessante i denne sammenhæng er, at den alfabetiske ordning, som brugtes $\mathrm{i}$ encyklopædier og ordbøger blev anset for at være den eneste brugbare. Jules Maciets skrev: ,(...) Enhver metode, der er baseret på den ræsonnerede sammenkædning af emner er arbitrær og afhænger af klassifikatorens personlige idéer." (Bouchon, 1997, s. 35). Maciets skepsis overfor systematisk ordnede vidensorganisationssystemer blev ikke delt af dem, der 100 år senere konstruerede tesauri og klassifikationssystemer for billeder.

Art \& Architecture Thesaurus er et struktureret vokabular, der omfatter 125.000 termer og andre oplysninger om begreber til beskrivelse "fine art, architecture, decorative arts, archival materials, and material culture." (Getty Research Institute, 2002). En del af de andre oplysninger er noter, der indeholder begrebsbestemmelser og definitioner. AAT dækker et bredt område, idet materiel kultur er inddraget; endvidere omfatter den kunstens historie fra oldtiden til i dag, og den geografiske dækning er global. AAT 
kan bruges til at beskrive genstande, tekstmaterialer, billeder, arkitektur og materiel kultur; dvs. dens anvendelsesområde omfatter både kunsthistoriens genstande og tekstmaterialer - ud over alt det andet.

I præsentationen bestemmes den også som en ,vidensbase" i kraft af de semantiske netværker, der dannes af forbindelser og ,stier“ mellem begreber. Den er opbygget efter de almindelige tesaurusprincipper med deskriptorer/foretrukne begreber, beslægtede begreber og en hierarkisk organisation. Der skelnes mellem tre typer relationer: Ækvivalens-, hierarki- og associationsrelationer. Ækvivalensrelationer bestemmes som termer, der repræsenterer det samme begreb (de betydningsmæssige implikationer problematiseres ikke). Deskriptorerne er termer, der ofte er brugt i forskningsdokumenter og autoritative publikationer. Disse deskriptorer må forstås som termer, der er alment accepterede inden for den kunsthistoriske forskningsinstitutionen. Hovedinddelingen i facetter, der har hver sin hierarkiske struktur, ser således ud:

- Associerede begreber (denne facet omfatter abstrakte begreber og fænomener, der knytter sig til studiet og udøvelsen af et bredt spektrum af menneskelig tænkning og aktivitet, herunder arkitektur og kunst i alle medier. Endvidere omfatter den teoretiske og kritiske forhold, ideologier, holdninger, samt sociale og kulturelle bevægelser)

- Fysiske attributter (materielle egenskaber som størrelse, form, kemiske egenskaber, tekstur, farve m.v.)

- Stilarter og perioder (alment accepterede termer for stilistiske grupperinger og kronologisk afgrænsede perioder, der er relevante for kunst og arkitektur (m.v.))

- Agenter (mennesker, grupper, organisationer, der identificeres ud fra beskæftigelse, aktivitet, fysiske eller mentale karakteristika, sociale roller eller sociale betingelser; det spænder fra kobbertrykkere til religiøse ordener)

- Aktiviteter (fysiske og mentale handlinger, metoder, processer m.v.; eksempelvis fremstilling, analyse, udstilling.

- Materialer (hele spektret af materialer, der indgår i kunstfrembringelse)

- Genstande (bygningsværker, billeder, skrevne dokumenter m.v.; det er den mest omfattende facet)

Disse facetter er et godt udtryk for, hvordan den kunstvidenskabelige diskurs er 'indskrevet' i andre diskurser, det er mest markant i den første facet: Associerede begreber. Denne facet 'åbner' i langt højere grad end de to nordamerikanske klassifikationssystemer for kunsthistoriske og kunstvidenskabelige værker, der ser kunsten i en social og institutionel sammenhæng; men denne forståelse kan ikke siges at præge den grundlæggende kategoristruktur.

Spektret i facetter er ordnet i et beskrivelsesformat, der har 27 felter. En tredjedel af disse facetter retter sig mod den fysiske beskrivelse, kategorisering og fremstilling af værket. Derefter kommer en række felter til beskrivelse af værkets ophav, fysiske tilstand, restaureringshistorie, ejerskabshistorie m.v. Af de $\varnothing$ vrige felter skal følgende fremdrages og et par af dem skal behandles lidt nærmere:

- stilarter, perioder, grupper, bevægelser

- indhold (emne)

- kontekst

- udstillings- og udlånshistorie

- beslægtede værker

- beslægtet visuel dokumentation

- relaterede teksthenvisninger

- modtagelse af kritikken

Indholdet (the subject matter) behandles på tre niveauer: beskrivelse, identifikation og fortolkning samt fortolkningshistorie og henvisning til de kilder, behandlingen er baseret på. Ligesom Sara Shatfords (1985) skema for billedindeksering, er dette felt baseret på Panofskys analysemetode med dens tre niveauer: præ-ikonografisk, ikonografisk og ikonologisk. (Panofsky, 1980, side 20). På beskrivelsesniveauet redegøres der for, hvad der eksempelvis ses på et billede (en kvinde, der sidder i en lukket 
have med et barn), på identifikationsniveauet fastlægges det, at det, vi ser er Maria med Jesusbarnet, på fortolkningsniveauet (eksemplet er et maleri med Mariæ bebudelse) fastlægges betydningerne: jomfruf $\varnothing \mathrm{dsel}$, arvesynd, død og frelse. I dette felt er der lagt en synsvinkel fra et bestemt kunsthistorisk paradigme ned over behandlingen af indholdet; jf. grupperne 753 og 755 i Dewey (henholdsvis Symbolik, allegori, mytologi, legende og Religion og religiøs symbolik) og den underordnede motivkategorisering i LCCS. Et generelt kritikpunkt der kan rettes mod dette er, at Panofskys teori er udviklet ud fra analyser af kunst i Renæssancen og Barokken, og at den er mindre brugbar til moderne kunst.

I feltet kontekst bestemmes dette begreb som: politiske, sociale, $\varnothing$ konomiske eller religiøse begivenheder eller omstændigheder, som kunst- eller arkitekturværket er knyttet sammen med både hvad angår fremstillingsomstændigheder og gennem tiden. $A A T$ er i princippet 'åben' for den 'nye' kunsthistorie (specielt gennem kategorien associerede begreber), men forståelsen af det felt, den dækker, og dermed dens principper for vidensorganisation, er dels baseret på stilarter og perioder, dels på den ikonografiske forskningstradition, dels på, hvad der empirisk kan undersøges og dokumenteres (fysiske attributter, agenter, materialer, aktiviteter). AAT kan ses som en meget udviklet, systematiseret og differentieret form for organisation af de oplysninger, der findes i catalogues raisonnés. ${ }^{9}$

Det hollandsk udviklede Iconclass er et emnespecifikt, internationalt klassifikationssystem for ikonografisk forskning og billeddokumentation. Det anvendes bl.a. i Kunst Indeks Danmark. Systemet er inddelt i 10 hovedgrupper og inddelingskriteriet er emne- eller motivkategorier:

\begin{tabular}{|ll|}
\hline 0. & Abstrakt, ikke virkelighedsgengivende \\
1. & kunst \\
2. & Religion og magi \\
3. & Mennesket \\
4. & Samfund, civilisation, kultur \\
5. & Abstrakte idéer og begreber \\
6. & Historie \\
7. & Bibelen \\
8. & Litteratur \\
9. & Klassisk mytologi og antik historie \\
\hline
\end{tabular}

Hovedgrupperne er hierarkisk underinddelte, bl.a. ud fra videnskabelige taxonomier (eksempelvis zoologi) og sekvensanalyser af tekster, der indeholder stof, der er brugt som motiver i kunsten (fortællingen om kong David i det Gamle Testamente, de enkelte fortællinger i Ovids Forvandlinger osv.). Iconclass baserer sig på en ikonografisk forskningstradition.

Det virtuelle Kunstmuseum dækker dansk kunst i det 20. århundrede. Til denne samling af visuelle billedrepræsentatitioner er der fire indgange, der danner grundstrukturen i vidensorganisationen:

- en kronologisk organisation, opdelt i tiår fra år 1900 til 1999

- opdeling i kunstarter (grafik og tegnekunst; fotografi; skulptur; maleri)

- temaer (Social kunst; objekt; store fortællinger; kompositioner; landskab; eksistens; portræt; menneskekroppen)

- stil (overskridelsens æstetik; abstraktioner; det moderne; det surreelle; ekspressivitet; farve og struktur; konkret kunst; popkunst; efter modernismen; tæt på virkeligheden)

Den kronologiske organisation i tiår og opdelingen i kunstarter er brugt på måder, der i princippet svarer til LCCS og Dewey. Derimod er kategoriseringen af temaer og stil foretaget ud fra specifikke danske forhold og udviklingslinier. Når man går ind i temaer og stil finder man en kort tekst, der giver et koncentreret overblik over udviklingen af det de pågældende temaer og stilarter. Behandlingen af temaer er set under synsvinkler, der på forskellig vis forankrer 
temaet i historien: kulturhistorien, kunsthistorien, mentalitetshistorien. Temaerne anslås i relation til disse historiske sammenhænge; men selvom det kun er anslag, lægges der et perspektiv ned over den billedsekvens, der "illustrerer" udviklingen af temaet. Teksten om social kunst (Kunst Indeks Danmark, 2000) er baseret på social og politisk historie:

„Gennem det 20. århundrede har kunstnerne, på forskellig vis, været optaget af sociale og politiske temaer. Samfundets normer og den politiske dagsorden er blevet belyst, kritiseret og fors $\emptyset \mathrm{gt}$ ændret, gennem en mængde medier og udtryk. Den socialrealistiske kunst, der skildrer arbejdernes trange levevilkår, slår igennem i begyndelsen af århundredet. Fagbevægelserne opstår og der kommer fokus på arbejdernes dårlige vilkår og disse afspejles i kunsten.” (...) Konceptkunsten, der er mere fokuseret på selve processen end på resultatet, kaster sig ud i projekter, der ofte har politisk karakter.“

Noget tilsvarende gør sig gældende for stil. Den første kategori, Overskridelsens cestetik, (Kunst Indeks Danmark, 2000) lægger en tematisering af kunstværkets ændrede karakter ind som perspektiv:

„Gennem det 20. århundrede har kunsten igen og igen overskredet de normer og konventioner, der ligger til grund for, at vi opfatter kunsten som kunst.

Mange værker bryder med samfundets forventninger til kunsten. De lever ikke op til den gængse regel om, at kunst er godt håndværk, og de gør op med det skønnes æstetik, der tidligere var forbundet med kunsten. Denne type grænseoverskridende kunst opfattes ofte som direkte frast $\varnothing$ dende, og mange føler derfor ikke, at værkerne kan defineres som kunst."

De her citerede tekster eksemplificerer et vigtigt træk ved vidensorganisationen i Det virtuelle Kunstmuseum, nemlig at kategoriseringen og dermed perspektivet på kunstværkerne både er præget af den specifikke danske sammenhæng, af nyere forskning og af det aktuelle, ,udvidede“ kunstbegreb. Der brydes altså (delvist) med opfattelsen af kunstens autonomi, kunstværkets klassiske karakter og de internationalt kodificerede betegnelser for stilarter og ismer. Dansk kunst forstås således ikke som en ,reeks" af internationale strømninger og påvirkninger. En anden pointe i Det virtuelle Kunstmuseum er, at man føres til nogle af de samme kunstværker, når man går ind forskellige steder i vidensorganisationssystemet; Dvs. de enkelte værker ses under ere synsvinkler, og ,illustrerer“ både periode, kunstart, tematik og stil.

\section{Afrunding}

Analysen af vidensorganisationen inden for feltet kunst og det dermed sammenhængende videnskabelige domæne kunsthistorie/kunstvidenskab viser, at den diskurs om kunsten, der er dominerende $\mathrm{i}$ vidensorganisationssystemerne er præget af kunstmuseernes historisk betingede udstillingspraksis, som denne er indskrevet i en række opfattelser, der kan føres tilbage til slutningen af Oplysningstiden. Den er også, i stor udstrækning, præget af en (modernistisk) opfattelse af kunstværket som værende i betydningens centrum og som bærer bestemte betydningsfulde former og et særegent betydningspotentiale. Endvidere er den præget af 'traditionelle' paradigmer inden for kunsthistorien (stilkritik, ikonografi, biografisk kontekstualisering). For det populærvidenskabelige kunsthistoriske oversigtsværk og for den populariserede kunstnermonografi er et centralt problem, at den 'nye' kunsthistorie kun i begrænset omfang har sat sig spor i vidensorganisationen. Hvad angår sekundære dokumenttyper som klassifikationssystemer og tesauri er et af problemerne, at de i deres grundkonstruktioner bygger på den 'traditionelle' kunsthistorie, hvilket 'blokerer' for en indeksering af den 'nye' kunsthistories dokumenter på deres egne præmisser. Problemet kan også formuleres som et 'usamtidighedsproblem', forstået på den måde, at dokumenter, der tilhører forskellige historiske lag i kunsthistoriens udvikling og dermed har forskellige vidensorganisationsprincipper i større eller mindre grad 'passer' ind klassifikationssy- 
stemets eller tesaurusens vidensorganisation. I $A A T$, Iconclass og Det virtuelle Kunstmuseum, der er konstrueret til organisation af (repræsentationer af) billeder, fordi der i sådanne systemer kan lægges ere perspektiver ned over det enkelte billede eller kunstværk, der således kan sættes ind i forskellige tolkningssammenhænge, som det ses i kimform i Det virtuelle Kunstmuseum.

\section{Referencer}

Bibliothekarisch-bibliographische Klassifikation. (1968) Tafeln für wissenschaftliche Bibliotheken. Band 21 : Sc Kunst. Kunstwissenschaft. Berlin : Methodisches Zentrum für wissenschaftliche Bibliotheken.

Bouchon, Chantal (1997): Le classement methodique de la collection de gravures et de photographies de la Bibliothèque des Arts Decoratifs. - Art Libraries Journal 22/3, 33-38.

Brier, s. et al. (1997). Faglitteraturens dokumenttyper i kommunikations- og videnskabsteoretisk belysning : Bind 1: Dokumenttypologiens almene teori og former. 6. foreløbige udgave. Kbhn. : Danmarks Biblioteksskole.

Bunkenborg, C \& Lommer, K (1995). Kunstmuseer og billedkunst ved en kulturpolitisk skillevej. Århus : Klim.

Dewey, M. (1990). Abridged Dewey Decimal Classification and Relative Indeks. Edtion 12. Albany, New York : Forest Press.

Dam Christensen, Hans (1999): Historiske konstruktioner. Passepartout, 11, 87-105.

Ferrari, Roberto C. (1999): The Art of Classification : Alternate Classification Systems in Art Libraries. Cataloging \& Classification Quarterly, 28(2), 7398.

Getty Research Institute (2002). Art \& Architecture
Thesaurus. Lokaliseret på den 13. september 2002 på World Wide Web: www.getty.edu/research/tools/ vocabulary/att

Hjørland, Birger (1997): Information seeking and Subject Representation : An Activity-Theoretical Approach to Information Science.Westport, Connecticut, London : Greenwood Press.

Jacobsen, S. (1993). Billedguide til kunstmuseerne $i$ Vejle Amt : Horsens Kunstmuseum, Vejle Kunstmuseum, Kunstmuseet Trapholt. Vejle : Vejle Kunstmuseums Forlag.

Janson, H.W. (1977): Verdenskunstens historie : Maleri. Skulptur. Arkitektur. Bind 1-3. Kbhn. : Politikens Forlag.

Korenic, Lyn (1997): Inside the Discipline, outside the Paradigm : Keeping Track of the New Art History. Art Libraries Journal 22/3, 12-18.

Kunst Indeks Danmark (2000). Det virtuelle Kunstmuseum. Lokaliseret på den 13. september 2002 på World Wide Web: www.detvirtuellekunstmuseum . $\mathrm{dk}$

Mortensen, Erik (1990): Kunstkritikkens og kunstopfattelsens historie i Danmark. Bind 1-2. - Kbhn. : Rhodos.

Nielsen, Hans Jørn (1997): Romaner af mange slags. Om indeksering, klassifikation og formidling af Skønlitteratur. Biblioteksarbejde, 50 (18.), 7-30.

Panofsky, Erwin (1980): Ikonografi og ikonologi. Visuel kommunikation 1. Kbhn. : Medusa, 9-21.

Royal Netherlands Academy of Arts and Sciences (1994). Iconclass. Lokaliseret på den 13. september 2002 på World Wide Web: www.iconclass.nl

Schaanning, Espen (1997): Vitenskap som skapt viden : Foucault og historisk praksis. - Oslo : Spartacus Forlag. 
Shatford, Sara (1986): Analyzing the Subject of a Picture: A Theoretical Approach. Cataloging and Classification Quarterly, Spring, 39-62.

Statens Museum for Kunst (2002). Kunst Indeks Danmark. Lokaliseret på den 13. september 2002 på World Wide Web: www.kid.dk

Sundt, Christine L. (1998). The Quest for Access to Images. Advances in Librarianship, 22, 87-106.

SuperLCCS (1998) Gale's Library of Congress Classification Schedules combined with Additions and Changes Through 1998: Classification: Class N, Fine Arts. - Washington : Library of Congress.

\section{Noter}

1. Arts Library of the University of California-Santa Barbara

2. Jeg anvender Birger Hjørlands kategorisering, Faglitteraturens dokumenttyper i kommunikations- og videnskabsteoretisk belysning, 1997, kapitel 4, 6 og 7

3. Jf. Hjørland, 1997, s. 45: “(...) knowledge is organized in learned institutions, in professionals, in journals, in libraries, and so on. Knowledge is produced as a part of human activities and tied to the division of labor in society."

4. Citeret efter: wwwku.dk/kunst/ordninger/ba 91.1. Formuleringen kan ikke tages som udtryk for den samlede forsknings- og undervisningspraksis. Den ses som udtryk for en institutionel forståelse.

5. Citeret efter: www.au.dk/hum/ukunst/humstudh.

6. Jfr. Dam Christensens kritiske analyse af Ny dansk kunsthistorie, Dam Christensen, 1999, s. 91-92

7. Ud fra Dansk Bogfortegnelse, 1999, kan 131 af de 274 dokumenter kategoriseres som populærvidenskabelige kunstmonografier, herunder udstillingskataloger til enkelte kunstneres udstillinger.

8. Daniel Preziosi: Rethinking Art History. New Haven \& London : Yale University Press, 1989. Jeg har ikke læst bogen og henviser til den, fordi den sammenkobler vidensorganisation i oversigtsværker og ,bibliografiske opdelinger“.

9. Se f.eks. The Vincent van Gogh Information Gallery [www.vangoghgallery.com] 